\title{
Do Firms Use Dividend Changes to Signal Future Earnings? An Investigation Based on Market Rationality
}

\author{
Ijaz $_{\text {Ali }}{ }^{1}$, Noor Muhammad ${ }^{2} \&$ Ali Gohar ${ }^{1}$ \\ ${ }^{1}$ Fahad Bin Sultan University Tabuk, Saudi Arabia \\ ${ }^{2}$ GIK Institute of Engineering sciences and Technology, Pakistan \\ Correspondence: Ijaz Ali, Assistant Professor, Fahad Bin Sultan University Tabuk, Saudi Arabia. E-mail: \\ ijaz_ims123@yahoo.com
}

Received: February 5, 2017

Accepted: February 24, 2017

Online Published: March 10, 2017

doi:10.5539/ijef.v9n4p20

URL: https://doi.org/10.5539/ijef.v9n4p20

\begin{abstract}
Are dividend changes informative? If yes, do they convey information about future earnings? Given the importance of the issue to corporate finance and because of the puzzling results of previous studies, we investigate the association among dividend changes, stock returns, and future earnings. Following 928 French and 995 German firms from 1991 to 2010, we expect that only those dividend changes will be positively associated with future earnings that result in abnormal stock returns. Inconsistent with our expectations, we find that the association between current dividend changes and future earnings changes for firms with the highest abnormal returns in the dividend change direction is not stronger than the rest of the firms. These findings cast doubt on the signaling theory, which claims that dividend changes convey information about changes in future earnings.
\end{abstract}

Keywords: dividends, reported earnings, signaling theory, abnormal returns, information content of dividends

\section{Introduction}

The dividend information content hypothesis is a longstanding hypothesis in the field of financial economics. Are dividends informative? If yes, do they convey information about changes in future earnings? These are two open ended questions. Given the importance of these issues to corporate finance, and because of the puzzling results of previous studies, we re-examine the empirical validity of the information content of dividends by examining the relationship of dividend changes with stock market reaction, and future earnings.

Miller and Modigliani (1961) suggest that dividends are paid notably because they can convey information about future cash flows. In other words, an increase in dividends would signal management's confidence that future earnings will increase sufficiently to cope with the dividend increase. Likewise, managers decrease dividends only if future earnings are expected to decline. An announcement of dividend increase is, therefore, considered a positive signal (good news), and a dividend decrease announcement is viewed as a negative signal (bad news).

Bhattacharya (1979), Miller and Rock (1985), and John and Williams (1985) developed models of dividend signaling theory. They suggest that dividends convey relevant information about firms' future prospects and that dividends are costly. Bhattacharya (1979) states that the transaction cost of share issues resulting from dividend payments is the cost of using dividends as a signal. Miller and Rock (1985) assume that firms forgo positive NPV investment opportunities by paying dividends. John and Williams (1985) and Bernheim (1991) declare the higher tax rates on dividends relative to capital gains as the signaling costs. Thus, in the context of the dividend signaling theory, we should observe: (i) a positive association between dividend changes and earnings changes in the years following the dividend change; (ii) abnormal stock returns around the dividend change announcements.

If the dividend literature overflows with empirical studies showing that announcements of increase (decrease) in dividends are systematically associated with positive (negative) abnormal stock returns, the prior evidence that dividend changes convey information about future earnings is weak. This makes market reactions to dividend announcements a puzzling phenomenon. If dividends have no relationship with future performance, why do capital markets react to dividend change announcements?

In this study, we assume that market forces react rationally to dividend changes and that they discriminate between dividend announcements that convey information on firms' future profitability from those that do not. 
We investigate the relationship between current dividend changes and changes in future earnings in two steps. In a first step, using all firms that changed their dividends, we analyze the relationship between current dividend changes and subsequent changes in earnings. In a second step we analyze the same relationship by considering only the dividend change announcements that trigger economically significant excess stock returns during the three days around the dividend change announcement dates.

By using US data, (Nissim \& Ziv, 2001) consider a particular model for measuring earnings expectations and find a positive association between dividend changes and future earnings. By using the model of Nissim and Ziv (2001), we examine the relationship between dividend changes and changes in future earnings for French and German firms. Both France and Germany are civil law countries, characterized as "relationship-oriented" systems. French and German firms prefer to pay dividend annually. Ownership, in both France and Germany, is concentrated and firms are monitored by a combination of large corporate shareholders, banks, and other inter-corporate relationships (e.g., co-owner family members etc). French and German listed firms provide us a sample of firms from countries with a reasonably homogenous highly developed set of legal institutions and comparatively high level legal enforcement systems. Given these characteristics we expect strong similarities between French and German markets. Furthermore, we expect relatively low information asymmetry problems and thus low market reaction to dividend change announcements.

\section{Market Reaction to Dividend Change Announcements}

A significant number of empirical studies have been conducted to investigate the impact of dividend change announcements on stock returns. These studies provide mixed evidence. Among others, Pettit (1976), and Aharony and Swary (1980) Sant and Cowan (1994), Dhillon et al. (1994), Christie et al. (1994), Michaely et al. (1995), Benartzi et al. (1997), Nissim and Ziv (2001), Koch and Sun (2004), Tsai and Wu (2015), and B. S. Lee and Mauck (2016) find evidence showing that dividend change announcements are positively associated with contemporaneous abnormal stock returns.

Asquith and Mullins (1983) examine the impact of dividend initiation on stockholders' wealth and report significant stock price increases around dividend initiations. Dielman and Oppenheimer (1984) report significantly more negative market reaction to announcements of dividend omissions by firms with a reputation of dividend consistency. Michaely et al. (1995) demonstrate that dividend initiations and omissions induce 3.4 percent and -7.0 percent average excess returns. Similarly, Lee and Ryan (2000) report a significant stock price reaction around dividend initiations and omissions. Apostolos et al. (2009) report that dividend initiations result in significant positive abnormal stock returns and that the price response to dividend initiations is inversely associated with the firms' information environment. Although these studies are based on the US firms, Travlos, Trigerorgis and Vafaes (2001) analyze firms headquartered in Cyprus. Gurgul, Madjosz and Mestel (2003) focus on the Austrian market, and Yilmaz and Gulay (2006) on Turkish firms. The advocates of the dividend signaling theory argue that abnormal stock returns triggered by dividend change announcements affirm they convey inside information about managements' assessment on firms' future prospects.

Some studies, however, do not find a significant relationship between dividend changes and subsequent stock market reaction. Benartzi, Michaely, and Thaler (1997) analyze the US market, Conroy, Eades, and Harris (2000) the Japanese market, Chen, Firth, and Gao (2002) the Chinese market, Abeyratna and Power (2002) the UK firms, (Andres, Betzer, Bongard, Haesner, \& Erik, 2013) the German firms, and (Al Qudah \& Badawi, 2015) Saudi firms. They do not find any significant relationship between dividend announcements and stock returns.

Based on these findings, we assume that market forces are rational and react only to those dividend change announcements which carry information about future earnings; in other words, abnormal stock returns around dividend announcements are significant only when these announcements do convey information on firms' future prospect. Therefore, we hypothesize that dividend changes are positively associated with changes in future earnings only if their announcements have resulted in highly significant stock market reactions.

\section{Dividend Changes and Changes in Future Earnings}

In order to investigate the relationship between dividend changes and changes in future earnings, a sizable number of studies have been conducted.

Brickley (1983) uses a sample of 35 firms that increased their dividends by more than 20 percent and finds a significant positive change in earnings of the dividend change year and the year after the dividend change. Healy and Palepu (1988) use a sample of 131 dividend initiators and 172 dividend omitters. They report a rising trend in earnings for dividend initiators, which starts in pre-initiation years and lasts till two years following the initiation year. Leftwich and Zmijewski (1994) suggest that a reduction in dividends indicates serious long term 
deterioration in a firm's future performance. Nissim and Ziv (2001), (Chen \& Kao, 2014), and (Liljeblom, Mollah, \& Rotter, 2015) find a positive association between dividend changes and changes in future earnings. Brav et al., (2005) present findings based on an extensive survey indicating that managers believe that dividend payments convey information to outsiders about future earnings.

Paradoxically some studies do not find evidence in support that dividend changes are positively associated with future earnings. Among others, Watts (1973) Penman (1983) DeAngelo et al. (1996), Benartzi et al. (1997), Grullon et al. (2005) report either very weak or no relationship between current dividend changes and future profitability. Koch and Sun (2004) demonstrate a negative relationship between dividend increases and future earnings changes and argue that dividend changes convey information about the persistence of past earnings changes, claiming that ".. all that is implied by a dividend increase is that past earnings increases will not 'reverse' in future periods". Jensen et al. (2010) report an earnings rebound in the post dividend change years for firms that announce dividend reductions. (Liu \& Chen, 2015) report a negative relation between dividend changes and return on assets.

In sum, the previous studies provide mix evidence on the relationship between dividend changes and changes in future earnings.

\section{Hypotheses Development}

To test the dividends-earnings relationship, we formulate the following alternative hypothesis:

\section{$\mathrm{H}_{1}$ : "Dividend changes are positively associated with future earnings".}

Rejection of the null hypothesis associated with $\mathrm{H}_{1}$ is consistent with the dividend signaling hypothesis that insiders (managers), who are more informed about the future prospects of their firms, use dividends to convey inside information to outsiders. However, the dividend signaling hypothesis is not systematically rejected if the null hypothesis is not rejected since dividend changes are not expected to convey information if they do not result in significant abnormal stock returns. Therefore, we also hypothesize that the only dividend changes that should be positively related to subsequent earnings changes are those that are informative, i.e. those that lead to economically significant abnormal returns around their announcement dates:

\section{$\mathrm{H}_{2}$ : "Dividend changes that result in economically significant stock price reaction are positively associated with future earnings".}

Rejection of the null hypothesis associated with $\mathrm{H}_{2}$ is consistent with the dividend signaling theory. On the other hand, if we fail to reject the null hypothesis, this will be evidence inconsistent with the dividend signaling hypothesis, which states that dividend changes convey information about changes in future earnings. Moreover, it will suggest that either dividend changes convey information about any other aspect (other than future earnings) of firms, or market forces react irrationally to dividend change announcements.

\section{Research Design}

In the first stage, to test hypothesis $\mathrm{H}_{1}$, we examine the association between dividend changes and changes in future earnings using all dividend change events. We use the following model used by Nissim and Ziv (2001). Nissim and Ziv (2001) argue that the previous studies examining the association between dividend changes and changes in future earnings omit relevant variables in their regression analyses correlated with the dividend changes. To this end, they include the return on equity (ROE) and past changes in earnings to control for the mean reversion and autocorrelation (e.g., momentum) in earnings. Furthermore, they consider that the magnitude of the relationship between earnings changes and dividend changes depends on whether dividend increases or decreases. Therefore they introduce two dummy variables to make a distinction between dividend increases and dividend increases.

$$
\begin{aligned}
\left(E_{T}-E_{T-1}\right) / B_{-I}= & \beta_{0}+\beta_{1 P} D P C_{0} \times R \Delta D I V_{0}+\beta_{1 N} D N C_{0} \times R \Delta D I V_{0} \\
& +\beta_{2} R O E_{T-I}+\beta_{3}\left(E_{0}-E_{-I}\right) / B_{-l}+\varepsilon_{T}
\end{aligned}
$$

where:

$\mathrm{E}_{\mathrm{T}}=$ earnings before extraordinary items for share $\mathrm{i}$ in year $\mathrm{t}$ (year 0 is the event year).

$\mathrm{B}_{-1}=$ book value of equity at the end of year -1 .

$\mathrm{R} \Delta \mathrm{DIV} \mathrm{V}_{0}=$ annual percentage change in the ordinary dividend payment in year 0.

$\mathrm{DPC}=$ dummy variable that takes the value one if dividends are increased and zero otherwise.

$\mathrm{DNC}=$ dummy variable that takes the value one if dividends are decreased and zero otherwise.

$\mathrm{ROE}_{\mathrm{T}-1}=$ earnings before extraordinary items in year $\mathrm{T}_{-1}$ scaled by the book value of equity at the end of year $\mathrm{T}_{-1}$. 
Following Grullon et al. (2005), we estimate cross-sectional regression coefficients for each year, then we compute time series means of the estimated coefficients and their corresponding t-statistics. On the basis of the signaling hypothesis we expect that a dividend increase will be followed by an increase in future earnings, while dividend decreasing firms should experience further deterioration in their future earnings.

In the second stage, to test the sub-hypothesis $\mathrm{H}_{2}$, we limit our sample to dividend change announcements that fulfill the following three conditions: i) the dividend change and the subsequent market reaction have positive relationship; ii) the change in dividends is at least 5\%; and iii) the three days abnormal return to the dividend change announcement is at least $1 \%$. We assume that investors are rational and can distinguish between genuine and fake signals conveyed by firm managers. Therefore, only dividend changes, that are positively associated with stock market returns, are positively related with future changes in earnings.

Here we do not consider the statistical significance but the economic significance of the market reaction, i.e. abnormal stock returns at dividend announcements. We select the threshold of $1 \%$ for abnormal stock returns, considering that abnormal returns lower than $1 \%$ do not result in economically significant changes in a firm's value.

We compute the change in dividends as the difference between the dividend announced in current year $(t)$ and the previous year's dividend, deflated by the previous year's dividend.

$$
\Delta D_{i, t}=\frac{D_{i, t}-D_{i, t-1}}{D_{i, t-1}}
$$

where:

$D_{i, t}=$ current year's dividend

$\Delta D_{i, t}=$ change in dividends for firm $i$ in year $t$.

We use market model to expected returns. The estimation window comprises of 120 trading days, ending 3 days before the event date. The event window comprises of three trading days centered by event day. We use abnormal stock returns as a proxy to measure market reaction to dividend changes.

$$
E\left(R_{i t}\right)=\alpha_{i}+\beta_{i} R_{m t}
$$

Where $\mathrm{R}_{\mathrm{it}}$ and $\mathrm{R}_{\mathrm{mt}}$ represent the stock $i$ and the SBF 250 Index returns on day $t$.

The abnormal returns on stock $i\left(\mathrm{AR}_{i t}\right)$ on day $t$ are equal to the difference between the actual returns and the expected returns $\left(\mathrm{ER}_{i t}\right)$.

$$
A R_{i t}=R_{i t}-E\left(R_{i t}\right)
$$

We compute the cumulative abnormal returns (CAR) for each dividend change announcement. This represents the market reaction to the concerned dividend announcement. The cumulative abnormal returns for firm " $i$ " in year " $t$ " are equal to the sum of abnormal returns of three days surrounding the event date.

$$
\text { CARit }=\sum_{t=-1}^{t=+1} \text { ARit }
$$

Where $t=0$ is the dividend change announcement day. If CAR is significantly different from zero it will be evidence in support of the dividend information content hypothesis.

To examine the relation between stock returns and dividend changes, the cumulative abnormal stock returns to dividend change announcements are regressed against dividend changes. For this purpose, the following regression model is estimated:

Where;

$$
C A R_{i t}=\beta_{0}+\beta_{1} D P C \times R \Delta D I V+\beta_{1} D N C \times R \Delta D I V+\varepsilon
$$

$\mathrm{CAR}_{i t}=$ cumulative abnormal return for stock $i$ in the 3-day period, surrounding the dividend change event date.

$\mathrm{DPC}=$ dummy variable that takes the value 1 if dividend increases and 0 otherwise.

$\mathrm{DNC}=$ dummy variable that takes the value 1 if dividend decreases and 0 otherwise.

If dividend changes convey inside information to outsiders about a firm's future prospects, as suggested by the dividend information content hypothesis, we expect $\beta_{l}$ to be positive and statistically significant.

\section{Sample Selection}

Our purpose was to test the empirical validity of the relationship between dividend changes and future earnings using European markets, but dividend announcement dates are not available for most of the European countries in Reuters 3000 Xtra database. Furthermore, UK based firms had to be excluded because majority of them announce dividends and earnings simultaneously. 
Using the Reuters 3000 Xtra database, we identify annual dividend announcements made between January 1991 and December 2009 by French and German firms. The rest of the data are extracted from Datastream database. A complete list of the sample criteria is as follows:

1) Firms classified as financials (codes that start from digit 40) by Global Industry Classification Standard (GICS) are excluded from the sample.

2) To be included in the sample a firm must be a dividend payer in the current year " $t$ " as well as in the previous year " $t-l$ " (We need two years of dividend payments to calculate the change in dividends). This criterion excludes dividend initiations and omissions.

In addition to the above mentioned criteria, for the three day stock price return computation, a firm should fulfill the following conditions as well:

3) The change in dividends should be at least 5 percent.

4) There should be no other announcements (e.g., special dividends, earnings, stock issue etc) made within 5 days interval of the dividend change announcement.

We require total assets to be available both in the current $(t)$ and in the preceding $\left(t_{-1}\right)$ year. Our primary set of firms consists of 901 French and 888 German firms. The sample includes 3061 dividend increased, and 836 dividend decreased events for France, and a total of 1523 increased and 406 decreased events for Germany. The preponderance of dividend increases over decreases is inconsistent with the studies that suggest that dividends are disappearing. Prior studies that find a reduction in the number (proportion) of dividend payers suggest that it could be because of the decline in the importance if dividends over time. If such is the case, dividend increased announcements should not be a preferred option for firms. These findings suggest that the phenomenon of dividend disappearance is triggered by reasons other than the decline in the importance of dividend payments.

Table 1 provides preliminary statistics on the dividend changes (R $\Delta$ DIV\%), the market value of equity (MV), the return on equity $(\mathrm{ROE} \%)$, and the return on assets (ROA\%), the total assets (TA), and the earnings before interest and taxes scaled by total assets (EBIT/TA\%) for dividend increasing firms (panel A), and for dividend decreasing firms (panel B).

Table 1. Summary Statistics

\begin{tabular}{|c|c|c|c|c|c|c|}
\hline & Mean & SD & $5 \%$ & $90 \%$ & $50 \%$ & $\mathrm{~N}$ \\
\hline \multicolumn{7}{|c|}{ A. Dividend Increases } \\
\hline $\mathrm{R} \Delta \mathrm{DIV} \%$ & 41.33 & 57.49 & 2.86 & 73.33 & 16.67 & 4616 \\
\hline MV (in millions of $€$ ) & 2949.92 & 8870.15 & 8.31 & 6480.86 & 182.67 & 5288 \\
\hline ROE \% & 16.09 & 23.23 & 2.67 & 29.23 & 13.76 & 5022 \\
\hline TA (in millions of $€$ ) & 4232.8 & 11700.0 & 12.9 & 10600.0 & 326.7 & 4943 \\
\hline EBIT/TA\% & 10.20 & 7.45 & 1.57 & 19.08 & 8.62 & 4697 \\
\hline \multicolumn{7}{|c|}{ B. Dividend Decreases } \\
\hline $\mathrm{R} \Delta \mathrm{DIV} \%$ & -57.43 & 22.79 & -75.45 & -5.26 & -28.80 & 1268 \\
\hline MV (in millions of $€$ ) & 1106.89 & 4595.42 & 6.44 & 1561.33 & 72.12 & 1262 \\
\hline $\mathrm{ROE} \%$ & 8.71 & 14.69 & -7.07 & 21.84 & 7.45 & 1184 \\
\hline TA (in millions of $€$ ) & 2253.8 & 7636.5 & 9.2 & 5003.8 & 152.9 & 1129 \\
\hline EBIT/TA\% & 7.29 & 7.58 & -1.09 & 14.68 & 6.01 & 1131 \\
\hline
\end{tabular}

Note. This table reports the characteristics of the sample firms. R $\triangle \mathrm{DIV}$ is the rate of change in dividends measured as the change in dividends scaled by last year's dividends [( $\left.\left.\operatorname{Div}_{0}-\operatorname{Div}_{-1}\right) / \operatorname{Div}_{-1}\right]$. MV, TA, ROE, and EBIT stand for market value, total assets, return on equity, and earnings before interest and taxes respectively. The data is winsorized. Any observation that falls more than three standard deviations away from the mean of the data under consideration is considered an outlier.

The average increase in dividends is 35.3percent, compared with an average decrease in dividends of nearly -32.43 percent. These results are inconsistent with prior empirical studies (e.g., Michaely, Thaler, and Womack (1995)) showing that dividend cuts are more extreme in magnitude than dividend increases. The rest of the table shows that firms that increase dividends are larger and more profitable than firms that cut dividends. 
Table 2. Number of firm year observations

\begin{tabular}{lcc}
\hline & France & Germany \\
\hline $\begin{array}{l}\text { Total number of dividend announcements } \\
\text { Less: }\end{array}$ & 11193 & 7894 \\
$\quad \begin{array}{l}\text { Number of interim dividend announcements } \\
\text { No change announcements plus initiations }\end{array}$ & 1340 & 664 \\
Number of observations used to test $\mathrm{H}_{1}$ & $\frac{4985}{4868}$ & $\frac{4517}{2713}$ \\
Less: & 2388 & 1861 \\
$\quad$ Announcts. made within 5 days interval of any other announcements & 8713 & 7042 \\
Number of observations excluded & 2480 & 852 \\
Total number of dividend change events used in $\mathrm{H}_{2}$ & \\
Note. This table reports the number of dividend events. The sample period is 1990-2010. Our primary set of firms consists of 901 French and \\
888 German firms. Dividend means ordinary dividends. Zero change announcements, initiations and omissions are excluded. Financial firms \\
are also excluded. To be included in the sample, a firm should pay dividends in both the current and previous year.
\end{tabular}

Table 3 provides statistics on the number of dividend increases, decreases, initiations, omissions, and no change firms in each year of our sample period. Initiators are firms that pay positive dividends in current year but have not paid dividends in last year. Omitters are firms that have paid dividends in last year but do not pay them in current year. No change firms are firms that do not change the amount of dividends in the current year (T) relative to the amount paid in the previous $\left(T_{-1}\right)$ year. Table 3 reports that both in France and Germany, firms that do not change their dividends (zero change firms) are far more in number than the other dividend groups. The resulting sample contains 4584 dividend increases, 1242 dividend decreases, and 7367 no-change events. These results are consistent with prior empirical studies (e.g., Grullon et al., 2005) showing that firms prefer to maintain their existing dividend levels, but in case of changes they prefer to increase dividends.

Table 3. Breakdown of dividend increases and dividend decreases per year

\begin{tabular}{cccccccccc}
\hline & \multicolumn{3}{c}{ France } & \multicolumn{3}{c}{ Germany } & \multicolumn{3}{c}{ All Firms } \\
\cline { 2 - 10 } Year & Incr. & Decr. & No change & Incr. & Decr. & No change & Incr. & Decr. & No change \\
\hline 1991 & 86 & 24 & 94 & 50 & 6 & 64 & 136 & 30 & 158 \\
1992 & 84 & 36 & 86 & 23 & 16 & 81 & 107 & 52 & 167 \\
1993 & 85 & 25 & 91 & 58 & 11 & 55 & 143 & 36 & 146 \\
1994 & 112 & 20 & 94 & 50 & 10 & 64 & 162 & 30 & 158 \\
1995 & 112 & 21 & 110 & 58 & 6 & 68 & 170 & 27 & 178 \\
1996 & 121 & 35 & 106 & 55 & 11 & 78 & 176 & 46 & 184 \\
1997 & 140 & 23 & 121 & 69 & 6 & 76 & 209 & 29 & 197 \\
1998 & 175 & 43 & 110 & 83 & 13 & 67 & 258 & 56 & 177 \\
1999 & 194 & 39 & 167 & 101 & 14 & 102 & 295 & 53 & 269 \\
2000 & 213 & 45 & 205 & 110 & 16 & 161 & 323 & 61 & 366 \\
2001 & 208 & 68 & 233 & 125 & 35 & 230 & 333 & 103 & 463 \\
2002 & 174 & 65 & 307 & 72 & 27 & 333 & 246 & 92 & 640 \\
2003 & 182 & 48 & 338 & 74 & 15 & 353 & 256 & 63 & 691 \\
2004 & 207 & 37 & 308 & 90 & 21 & 330 & 297 & 58 & 638 \\
2005 & 222 & 43 & 288 & 126 & 14 & 311 & 348 & 57 & 599 \\
2006 & 249 & 42 & 304 & 150 & 17 & 337 & 399 & 59 & 641 \\
2007 & 270 & 46 & 338 & 152 & 26 & 396 & 422 & 72 & 734 \\
2008 & 126 & 119 & 394 & 74 & 135 & 381 & 200 & 254 & 775 \\
2009 & 101 & 57 & 159 & 3 & 7 & 27 & 104 & 64 & 186 \\
Total & 3061 & 836 & 3853 & 1523 & 406 & 3514 & 4584 & 1242 \\
\hline
\end{tabular}

Note. This table reports the number of dividend increases, decreases, initiations, omissions, and no change firms in each year of our sample period. Initiators are firms that pay positive dividends in current year but have not paid dividends in last year. Omitters are firms that have paid dividends in last year but do not pay them in current year. No change firms are firms that do not change the amount of dividends in the current year $(\mathrm{T})$ relative to the amount paid in the previous $\left(\mathrm{T}_{-1}\right)$ year.

\section{Empirical Findings}

To test the relationship between current dividend changes and future earnings, first we consider equation [1] by using all dividend change events. In order to reduce the problems associated with residual cross-correlation, we follow Fama and MacBeth (1973) in estimating the coefficients of the regression model. We estimate cross-sectional regression coefficients for each year and compute time-series means of the computed regression coefficients. T-statistics are obtained by dividing mean values by their standard errors. 


\subsection{Hypothesis 1}

Table 4 reports the results of equation (1). In this table we estimate the regression coefficients by using all firm year observations. Panel A of Table 4 suggests that the positive dividend changes in year zero are positively associated with earnings changes in year 1 and 2; and are significant in year 2 only. The coefficient for positive dividend changes, $\beta_{I P}$, is equal to 0.02 when $\mathrm{T}=1$ and $\mathrm{T}=2$; for negative dividend changes it is positive (0.08) and significant in year $\mathrm{T}=1$ only. The coefficients for both positive and negative changes become negative in year three; that is when $\mathrm{T}=3$. This suggests a recovery, in terms of profitability, of dividend decreased firms, and a decline in the earnings of firms that increased dividends.

Panel B of Table 4 reports annual cross-sectional regression coefficients for dividend changes. It helps to analyze the relationship between dividend changes and changes in future earnings in more detail. It also helps to determine whether the relationship between dividend changes and changes in future earnings varies through time systematically. We observe that the coefficients of positive dividend changes are positive and significant only for 21.05 percent of the years when $\mathrm{T}=1$ and 26.32 percent when $\mathrm{T}=2$. Similarly, the coefficients for negative dividend changes are positive and significant for 36.8 percent and 15.79 percent of the total years (19) when $\mathrm{T}=1$ and $\mathrm{T}=2$ respectively. For year $T=3$, the number declines to 5.26 percent for both dividends increased and decreased firms. Furthermore in year $\mathrm{T}=3$, the number of years with negative and significant coefficients rises to 15.79 percent from 5.25 (10.52) percent for dividend increased (decreased) firms. These findings confirm that firms that cut dividends due to poor performance start to recover in the third year after dividend changes. Similarly, firms that announce dividend increases, face a deterioration in their profitability in year $\mathrm{T}=3$. Consistent with previous studies, these results indicate a weak relationship between current dividend changes and changes in future earnings.

Table 4. Regression of earnings changes on dividend changes

\begin{tabular}{|c|c|c|c|c|c|c|c|}
\hline \multicolumn{8}{|c|}{$\begin{array}{l}\text { Panel A: Time series Means of the cross-sectional regression coefficients } \\
\left(\mathbf{E}_{0}-\mathbf{E}_{-1}\right) / \mathbf{B}_{-1}=\beta_{0}+\beta_{1 P} \mathrm{DPC}_{0} \times \mathbf{R} \Delta D I V_{0}+\beta_{1 N} \mathrm{DNC}_{0} \times \mathbf{R} \Delta D I V_{0}+\beta_{2} \mathbf{R O E}_{\mathrm{T}-1}+\beta_{3}\left(\mathbf{E}_{0}-\mathbf{E}_{-1}\right) / \mathbf{B}_{-1}+\varepsilon_{\mathrm{T}}\end{array}$} \\
\hline Year & & $\beta_{l p}$ & $\beta_{\ln }$ & $\beta_{2}$ & $\beta_{3}$ & $\beta_{0}$ & Mean Adjusted $\mathrm{R}_{2}$ \\
\hline \multirow[t]{2}{*}{$\mathrm{T}=1$} & Mean & 0.02 & 0.08 & -0.09 & -0.37 & 0.02 & 0.18 \\
\hline & t-statistics & 1.72 & 2.83 & -0.76 & -5.88 & 1.46 & \\
\hline \multirow[t]{2}{*}{$\mathrm{T}=2$} & Mean & 0.02 & 0.02 & 0.58 & -0.44 & -0.05 & 0.39 \\
\hline & t-statistics & 2.10 & 0.80 & 4.18 & -6.85 & -3.74 & \\
\hline \multirow[t]{2}{*}{$\mathrm{T}=3$} & Mean & -0.01 & -0.04 & -0.13 & 0.15 & 0.01 & 0.12 \\
\hline & t-statistics & -0.83 & -0.95 & -1.47 & 1.63 & 1.33 & \\
\hline
\end{tabular}

Panel B: Annual cross sectional regression coefficients of dividend changes

$\left(\mathrm{E}_{\mathrm{T}}-\mathrm{E}_{\mathrm{T}-1}\right) / \mathrm{B}_{-1}=\beta_{0}+\beta_{1 P} \mathrm{DPC}_{0} \times \mathrm{R} \Delta \mathrm{DIV} \mathrm{V}_{0}+\beta_{1 N} \mathrm{DNC}_{0} \times \mathrm{R} \Delta \mathrm{DIV} \mathrm{V}_{0}+\boldsymbol{\beta}_{2} \mathrm{ROE}_{\mathrm{T}-1}+\boldsymbol{\beta}_{3}\left(\mathrm{E}_{\mathbf{0}}-\mathrm{E}_{-1}\right) / \mathrm{B}_{-1}+\varepsilon_{\mathrm{T}}$

\begin{tabular}{|c|c|c|c|c|c|c|c|c|c|c|c|c|}
\hline \multirow[b]{2}{*}{ Year } & \multicolumn{4}{|c|}{$\mathrm{T}=1$} & \multicolumn{4}{|c|}{$\mathrm{T}=2$} & \multicolumn{4}{|c|}{$\mathrm{T}=3$} \\
\hline & $\beta_{1 \mathrm{P}}$ & $\mathrm{t}\left(\beta_{1 \mathrm{P}}\right)$ & $\mathrm{B}_{1 \mathrm{~N}}$ & $t\left(B_{1 N}\right)$ & $\beta_{1 \mathrm{P}}$ & $\mathrm{t}\left(\beta_{1 \mathrm{P}}\right)$ & $\mathrm{B}_{1 \mathrm{~N}}$ & $t\left(B_{1 N}\right)$ & $\beta_{1 \mathrm{P}}$ & $\mathrm{t}\left(\beta_{1 \mathrm{P}}\right)$ & $\mathrm{B}_{1 \mathrm{~N}}$ & $t\left(B_{1 N}\right)$ \\
\hline 1991 & -0.04 & -2.23 & 0.18 & 3.03 & -0.02 & -1.63 & 0.07 & 2.04 & 0.01 & 0.56 & -0.02 & -0.32 \\
\hline 1992 & -0.01 & -0.16 & 0.07 & 0.89 & -0.03 & -0.46 & 0.10 & 1.5 & 0.02 & 0.22 & -0.14 & -1.93 \\
\hline 1993 & 0.10 & 2.11 & -0.15 & -2.40 & 0.11 & 3.03 & -0.09 & -1.84 & -0.25 & -2.44 & 0.05 & 0.38 \\
\hline 1994 & -0.03 & -0.98 & -0.03 & -0.19 & 0.03 & 1.09 & -0.02 & -0.19 & 0.03 & 0.82 & -0.18 & -1.07 \\
\hline 1995 & 0.00 & 0.01 & 0.19 & 2.94 & 0.01 & 0.25 & -0.13 & -1.00 & 0.02 & 0.72 & 0.07 & 0.44 \\
\hline 1996 & 0.04 & 3.06 & -0.12 & -1.84 & 0.02 & 1.87 & -0.20 & -5.05 & -0.06 & -2.9 & 0.26 & 2.73 \\
\hline 1997 & 0.01 & 0.33 & 0.09 & 0.96 & 0.01 & 0.74 & 0.09 & 1.02 & -0.02 & -0.59 & -0.04 & -0.26 \\
\hline 1998 & 0.02 & 1.31 & 0.10 & 1.61 & -0.01 & -0.81 & 0.06 & 1.35 & 0.03 & 1.5 & -0.05 & -0.5 \\
\hline 1999 & -0.02 & -1.68 & -0.03 & -0.39 & 0.00 & -0.32 & 0.02 & 0.25 & -0.08 & -3.57 & -0.19 & -1.32 \\
\hline 2000 & 0.10 & 4.53 & 0.31 & 4.25 & 0.07 & 3.9 & 0.00 & 0.07 & -0.02 & -0.66 & 0.03 & 0.27 \\
\hline 2001 & 0.03 & 1.27 & 0.07 & 0.98 & 0.04 & 3.05 & -0.11 & -1.96 & 0.02 & 0.88 & -0.05 & -0.56 \\
\hline 2002 & 0.01 & 0.53 & 0.21 & 4.95 & 0.01 & 0.64 & 0.22 & 4.93 & 0.02 & 0.71 & -0.15 & -2.44 \\
\hline 2003 & 0.00 & 0.24 & 0.09 & 1.85 & 0.00 & 0.31 & 0.08 & 1.66 & 0.01 & 0.96 & -0.04 & -0.65 \\
\hline 2004 & 0.02 & 1.22 & -0.02 & -0.18 & 0.00 & 0.22 & -0.02 & -0.21 & -0.02 & -1.1 & 0.01 & 0.07 \\
\hline 2005 & 0.00 & 0.22 & 0.05 & 0.77 & 0.00 & 0.1 & -0.02 & -0.43 & 0.00 & -0.21 & 0.17 & 0.93 \\
\hline 2006 & 0.06 & 4.68 & 0.10 & 1.31 & 0.07 & 5.26 & 0.04 & 0.57 & 0.06 & 3.19 & 0.13 & 1.28 \\
\hline 2007 & 0.01 & 1.07 & 0.33 & 4.55 & 0.01 & 0.53 & 0.30 & 4.09 & 0.00 & -0.02 & -0.53 & -4.06 \\
\hline 2008 & -0.01 & -0.49 & 0.08 & 2.71 & -0.01 & -0.62 & 0.02 & 0.89 & & & & \\
\hline
\end{tabular}

Note. This table reports regression estimates relating earning changes to dividend changes. ET is the net earnings in year T (year 0 is the event year). B-1 is the book value of owner's equity at the end of year -1 . R $\triangle \mathrm{DIV}$ is the annual rate of change in ordinary dividends, computed as the change in dividends scaled by last year's dividends. DPC (DNC) is equal to one for dividend increases (decreases) and zero otherwise. ROE stands for returns on equity. Following Fama and MacBeth (1973), first we estimate intercept and slope coefficients from annual regressions of each year of the sample period 1991-2010, then we compute time-series averages of the cross sectional regression coefficients. The t-statistics are obtained by dividing the mean values by their standard errors. In table 4 , positive and significant coefficients are highlighted. 


\subsection{Hypothesis 2}

Prior findings in support of positive association between abnormal stock returns and dividend changes are considered evidence in support of the dividend signaling hypothesis. In other words, market participants react to dividend changes because these changes have information content about firms' future profitability. In order to examine whether dividend changes are related to subsequent share price reactions, we compute three days market adjusted abnormal stock returns around the dividend change announcements. We assume that market forces can distinguish between genuine and fake dividend change signals. Thus the relationship between dividend changes and future earnings is expected to be positive and significant only if market participants react to the dividend changes in the dividend change direction and the magnitude of dividend changes and market reaction is reasonably large. To test the relationship between dividend changes and future earnings changes we consider only the dividend change announcements where the dividend increase (decrease) is at least 5(-5) percent and the market reaction is at least 1(-1) percent. We use annual rather than interim data because dividends are set in response to annual rather than interim earnings (Watts, 1973).

Table 5 presents the distribution of dividend changes and the direction of market response to these changes. Total number of dividend increases (decreases) that triggered market adjusted abnormal returns is 2480 (847). The excess returns are computed based on the market model. Consistent with the previous findings (e.g., Asquith \& Mullins, 1983; Benesh, Keown, \& Pinkerton, 1984; Born, Mozer, \& Officer, 1988; Dhillon \& Johnson, 1994; Healy, Hathorn, \& Kirch, 1997) we find that a substantial proportion of firms experience adverse market reaction to dividend change announcements. Furthermore, relative to positive dividend changes, negative dividend changes are frequently negatively associated with subsequent excess returns. This could be because minor negative changes may prove a positive signal when market forces expect large dividend cuts.

Table 5. Direction of market reaction to the announcement of dividend increases or decreases

\begin{tabular}{ccccccc}
\hline & \multicolumn{3}{c}{ Dividend Increases } & \multicolumn{3}{c}{ Dividend Decreases } \\
\cline { 2 - 7 } Year & Firms & Positive returns $\%$ & Negative returns $\%$ & Firms & Positive returns\% & Negative returns\% \\
\hline 1991 & 59 & 75.0 & 25.0 & 10 & 20.0 & 80.0 \\
1992 & 58 & 45.0 & 55.0 & 24 & 43.5 & 56.5 \\
1993 & 62 & 57.1 & 42.9 & 17 & 53.0 & 47.0 \\
1994 & 72 & 85.0 & 15.0 & 8 & 37.5 & 62.6 \\
1995 & 66 & 78.9 & 21.1 & 12 & 33.3 & 66.6 \\
1996 & 80 & 46.4 & 53.6 & 28 & 53.5 & 46.4 \\
1997 & 94 & 69.2 & 30.8 & 14 & 57.1 & 42.8 \\
1998 & 87 & 65.7 & 34.3 & 24 & 50.0 & 50.0 \\
1999 & 148 & 67.4 & 32.6 & 25 & 54.5 & 45.4 \\
2000 & 179 & 69.2 & 30.8 & 40 & 50.0 & 50.0 \\
2001 & 141 & 47.8 & 52.2 & 63 & 58.6 & 41.3 \\
2002 & 134 & 53.6 & 46.4 & 60 & 43.9 & 56.1 \\
2003 & 148 & 65.4 & 34.6 & 41 & 43.9 & 56.0 \\
2004 & 176 & 73.2 & 26.8 & 43 & 35.7 & 64.2 \\
2005 & 258 & 74.2 & 25.8 & 42 & 40.0 & 60.0 \\
2006 & 276 & 78.9 & 21.1 & 42 & 38.0 & 61.9 \\
2007 & 262 & 70.9 & 29.1 & 39 & 59.0 & 41.0 \\
2008 & 108 & 34.7 & 65.3 & 119 & 37.6 & 62.4 \\
2009 & 72 & 79.2 & 20.8 & 33 & 34.9 & 65.1 \\
\hline
\end{tabular}

Note. This table reports the number of dividend change announcements and the proportion of the dividend change events that trigger positive (or negative) returns. "Firms" are the number of firms that change their annual dividend per share during the year $t$. A dividend change is defined as the difference between the announced dividend in year $t$ and the prior year's dividend. Dividend changes announced during the 5 days interval of earnings announcements or any other special dividends announcements are excluded. Positive (negative) returns are the proportion of three day cumulated abnormal returns computed by using market model. Here we consider all dividend change events irrespective of the magnitude of dividend change and returns.

Table 6 presents descriptive statistics for the sample used to test hypotheses 2 (H2). Panel A of table 6 considers all dividend events for which stock price data is available for computing the three days abnormal stock returns. The sample selection criteria resulted in a sample of 8780 observations: 847 dividend decreases, 2480 dividend increases, and 5453 no-change observations. Similar to DeAngelo and DeAngelo (1990), and Nissim and Ziv 
(2001) we find that dividend increases, although more frequent than dividend decreases, are smaller in magnitude. Panel A of table 6 reflects that the rate of change in dividend per share relative to the previous year dividend has a mean of 35.02 percent for dividend increases and 51.4 percent for dividend decreases. Furthermore, the same panel of the same table shows that market reaction to dividend increase announcements is positive and significant. The mean stock return during the three days surrounding the dividend increase announcements (days-1, 0 , and 1) is 1.04 percent ( $t$-statistic 13.02). The full sample of dividend decrease announcements and no change events trigger only 0.3 and 0.2 percent of statistically insignificant positive returns. The number of no change events exceeds the number of dividend change events; the reason is that most companies change their dividends only once every few years.

Unlike panel A, panel B of table 6 considers only the dividend announcements that are positively associated with their corresponding three days cumulative abnormal stock returns. Panel B reflects that the mean stock return during the three days surrounding the announcement date is -4.50 percent for the dividend decrease sample ( $t$-statistic 14.91), 5.50 percent ( $t$-statistic 35.61$)$ for the dividend increase sample.

In contrast to the first two panels, panel $\mathrm{C}$ of table 6 considers only the dividend changes that are at least 5 percent and trigger accumulative abnormal returns not less than 1 percent. In addition these dividend changes are positively associated with their corresponding three days accumulative abnormal stock returns. The resulting firm-year sample that fulfills the three conditions includes 1267 observations: 1057 dividend increases, and 210 dividend decreases. Panel $\mathrm{C}$ reflects that dividend increases (decreases) trigger 6.5 (-6.1) percent of mean abnormal stock returns.

Table 6. Descriptive statistics on the distributions of the cumulative abnormal returns and dividend changes

\begin{tabular}{|c|c|c|c|c|c|c|c|}
\hline \multicolumn{8}{|c|}{ Panel A: All dividend announcements } \\
\hline & Mean & SD & $10 \%$ & $25 \%$ & $50 \%$ & $75 \%$ & $90 \%$ \\
\hline \multicolumn{8}{|c|}{ Dividend Decreases (847) } \\
\hline $\mathbf{R} \Delta \mathbf{D I V}$ & -0.514 & 0.361 & -0.1 & -0.74 & -0.444 & -0.193 & -0.079 \\
\hline $\boldsymbol{R}$ & 0.003 & 0.079 & -0.072 & -0.029 & -0.000 & 0.028 & 0.077 \\
\hline t-statistics & $(1.01)$ & & & & & & \\
\hline p-value & 0.311 & & & & & & \\
\hline \multicolumn{8}{|c|}{ Dividend Increases (2480) } \\
\hline $\mathbf{R} \Delta \mathbf{D I V}$ & 0.350 & 0.323 & 0.071 & 0.101 & 0.200 & 0.502 & 1.00 \\
\hline $\boldsymbol{R}$ & $0.01 * * *$ & 0.065 & -0.045 & -0.016 & 0.008 & 0.048 & 0.098 \\
\hline t-statistics & $(13.02)$ & & & & & & \\
\hline p-value & 0.000 & & & & & & \\
\hline \multicolumn{8}{|c|}{ No Change (5453) } \\
\hline $\boldsymbol{R}$ & 0.002 & 0.055 & -0.045 & -0.021 & 0.000 & 0.029 & 0.065 \\
\hline t-statistics & $(0.900)$ & & & & & & \\
\hline p-value & 0.368 & & & & & & \\
\hline \multicolumn{8}{|c|}{ All Firms (8780) } \\
\hline $\mathbf{R} \triangle \mathrm{DIV}$ & 0.139 & 0.754 & -0.501 & 0.000 & 0.051 & 0.243 & 1.00 \\
\hline $\boldsymbol{R}$ & $0.01 * * *$ & 0.068 & -0.049 & -0.019 & 0.005 & 0.043 & 0.091 \\
\hline t-statistics & (11.174) & & & & & & \\
\hline p-value & 0.000 & & & & & & \\
\hline \multicolumn{8}{|c|}{ Panel B: Dividend announcements with positive relation between the dividend change and associated abnormal stock returns } \\
\hline & Mean & SD & $10 \%$ & $25 \%$ & $\mathbf{5 0 \%}$ & $75 \%$ & $90 \%$ \\
\hline \multicolumn{8}{|c|}{ Dividend Decreases (333) } \\
\hline $\mathbf{R} \Delta \mathrm{DIV}$ & -0.502 & 0.250 & -0.860 & -0.750 & -0.353 & -0.133 & -0.063 \\
\hline $\boldsymbol{R}$ & $-0.045^{* * *}$ & 0.055 & -0.112 & -0.059 & -0.028 & -0.01 & -0.003 \\
\hline t-statistics & (14.917) & & & & & & \\
\hline p-value & 0.000 & & & & & & \\
\hline \multicolumn{8}{|c|}{ Dividend Increases (1266) } \\
\hline $\mathbf{R} \Delta \mathrm{DIV}$ & 0.401 & 0.391 & 0.053 & 0.021 & 0.245 & 0.630 & 1.12 \\
\hline $\boldsymbol{R}$ & $0.055^{* * *}$ & 0.055 & 0.005 & 0.015 & 0.040 & 0.077 & 0.123 \\
\hline t-statistics & $(35.612)$ & & & & & & \\
\hline p-value & 0.000 & & & & & & \\
\hline \multicolumn{8}{|c|}{ All Firms (1599) } \\
\hline $\mathbf{R} \Delta \mathrm{DIV}$ & 0.347 & 0.710 & -0.450 & 0.001 & 0.080 & 0.271 & 1.21 \\
\hline $\boldsymbol{R}$ & $0.034 * * *$ & 0.068 & -0.029 & 0.003 & 0.025 & 0.064 & 0.113 \\
\hline t-statistics & (19.976) & & & & & & \\
\hline p-value & 0.000 & & & & & & \\
\hline
\end{tabular}




\begin{tabular}{|c|c|c|c|c|c|c|c|}
\hline \multicolumn{8}{|c|}{ Panel C: Dividend changes that fulfill the three restrictive conditions of the study } \\
\hline & Mean & SD & $10 \%$ & $25 \%$ & $50 \%$ & $75 \%$ & $90 \%$ \\
\hline \multicolumn{8}{|c|}{ Dividend Decreases (210) } \\
\hline $\mathbf{R} \Delta \mathrm{DIV}$ & -.603 & .302 & -.852 & -.453 & -.201 & -.01 & -.000 \\
\hline $\boldsymbol{R}$ & $-.061 * * *$ & .059 & -.129 & -.076 & -.042 & -.023 & -.013 \\
\hline t-statistics & $(15.031)$ & & & & & & \\
\hline p-value & 0.000 & & & & & & \\
\hline \multicolumn{8}{|c|}{ Dividend Increases (1057) } \\
\hline $\mathbf{R} \Delta \mathrm{DIV}$ & .456 & .435 & .052 & .021 & .247 & .66 & 1.15 \\
\hline $\boldsymbol{R}$ & $0.065^{* * *}$ & .055 & .015 & .026 & .050 & .085 & .135 \\
\hline t-statistics & $(38.33)$ & & & & & & \\
\hline p-value & 0.000 & & & & & & \\
\hline \multicolumn{8}{|c|}{ All Firms (1267) } \\
\hline $\mathbf{R} \Delta \mathrm{DIV}$ & .377 & .791 & -.460 & .001 & .070 & .311 & 1.28 \\
\hline $\boldsymbol{R}$ & $.044 * * *$ & .073 & -.034 & .015 & .040 & .077 & .123 \\
\hline t-statistics & $(21.57)$ & & & & & & \\
\hline p-value & 0.000 & & & & & & \\
\hline
\end{tabular}

Note. The $10 \%$ is the 10 th percentile of the distribution (i.e., $10 \%$ of the observations have a lower value), $25 \%$ is the twenty-fifth percentile. The R $\Delta$ DIV is the relative change in dividends defined as the annual change in dividends relative to the value at the previous year scaled by the previous year dividend. $\mathrm{R}$ refers to the three day cumulative abnormal stock returns based on the market model. Panel A considers all dividend announcements for which we have the data required for computing abnormal returns. Panel B considers only the dividend change announcements that have positive association with their abnormal stock returns. Panel C considers the dividend change events that fulfill the three conditions: i) Dividend changes and cumulative abnormal returns are positively associated; ii) Dividend changes are at least 5 percent; iii) Cumulative abnormal returns are at least $1(-1)$ percent.

*** Significant at the 0.01 level using a two-tailed Student's t-test for the means.

Inconsistent with Nissim and Ziv (2001), we find that the market reaction to dividend increases is higher than that of dividend decreases.

\section{1) Relation between Dividend Changes and Abnormal Returns}

In order to analyze the relation between stock returns and dividend changes, we estimate equation (6). We use the three commonly used techniques for estimating the model with panel data: the pooled ordinary least squares (OLS). The fixed effects model (FEM). and the random effects model (REM). The output from the regression is reported in Table 7. The firm-year sample used in panel A includes all dividend announcements for which we have the necessary data to compute abnormal stock returns. Panel B considers only those dividend changes that are positively associated with their subsequent stock price returns. Panel $\mathrm{C}$ considers only the dividend changes that are at least 5 percent and trigger cumulative abnormal returns not less than 1 percent; moreover, dividend changes and cumulative abnormal returns should be positively associated.

Table 7. Regression of market reaction on dividend changes

\begin{tabular}{|c|c|c|c|}
\hline \multicolumn{4}{|c|}{ Panel A: All dividend announcements } \\
\hline \multirow[t]{2}{*}{ Coefficient } & \multicolumn{3}{|c|}{$\mathrm{CAR}_{\mathrm{it}}=\beta_{0}+\beta_{1} \mathrm{DPC} \times \mathrm{R} \Delta \mathrm{DIV}+\boldsymbol{\beta}_{1} \mathrm{DNC} \times \mathrm{R} \Delta \mathrm{DIV}+\varepsilon$} \\
\hline & FEM & REM & Pooled OLS \\
\hline \multirow[t]{2}{*}{ Constant } & $0.01 * * *$ & $0.01 * * *$ & $0.01 * * *$ \\
\hline & $(8.69)$ & $(7.21)$ & $(9.26)$ \\
\hline \multirow[t]{2}{*}{$\mathrm{DPC} \times \mathrm{R} \Delta \mathrm{DIV}$} & $0.26^{* * *}$ & $0.20 * * *$ & $0.21^{* * *}$ \\
\hline & $(4.49)$ & $(4.68)$ & $(4.69)$ \\
\hline \multirow[t]{2}{*}{$\mathrm{DNC} \times \mathrm{R} \Delta \mathrm{DIV}$} & -0.01 & -0.04 & -0.04 \\
\hline & $(-0.19)$ & $(-1.21)$ & $(-1.39)$ \\
\hline $\mathrm{N}$ & 3327 & 3327 & 3327 \\
\hline Adjusted $\mathrm{R}^{2}$ & 0.008 & 0.008 & 0.006 \\
\hline Test F & & & $19.54 * * *$ \\
\hline Hausman Test & 3.01 & & \\
\hline
\end{tabular}


Panel B: Dividend announcements with positive relation between the dividend change and associated abnormal stock returns

\begin{tabular}{|c|c|c|c|}
\hline Coefficient & \multicolumn{3}{|c|}{$\mathrm{CAR}_{\mathrm{it}}=\beta_{0}+\beta_{1} \mathrm{DPC} \times \mathrm{R} \Delta \mathrm{DIV}+\beta_{1} \mathrm{DNC} \times \mathrm{R} \Delta \mathrm{DIV}+\varepsilon$} \\
\hline \multirow{3}{*}{ Constant } & FEM & REM & Pooled OLS \\
\hline & $0.02 * * *$ & $0.03 * * *$ & $0.03 * * *$ \\
\hline & $(15.71)$ & $(17.49)$ & $(21.35)$ \\
\hline \multirow[t]{2}{*}{$\mathrm{DPC} \times \mathrm{R} \Delta \mathrm{DIV}$} & $0.90 * * *$ & $0.24 * * *$ & $0.22 * * *$ \\
\hline & $(8.55)$ & $(5.29)$ & $(5.03)$ \\
\hline \multirow[t]{2}{*}{$\mathrm{DNC} \times \mathrm{R} \Delta \mathrm{DIV}$} & $0.744 * * *$ & $0.93 * * *$ & $0.94 * * *$ \\
\hline & $(7.77)$ & $(12.05)$ & $(12.17)$ \\
\hline $\mathrm{N}$ & 1599 & 1599 & 1599 \\
\hline Adjusted $\mathrm{R}^{2}$ & 0.13 & 0.10 & 0.10 \\
\hline Test F & & & $61.30 * * *$ \\
\hline Hausman Test & $50.94 * * *$ & & \\
\hline \multicolumn{4}{|c|}{ Panel C: Dividend changes that fulfill the three restrictive conditions of the study } \\
\hline \multirow[t]{2}{*}{ Coefficient } & \multicolumn{3}{|c|}{$\mathrm{CAR}_{\mathrm{it}}=\beta_{0}+\beta_{1} \mathrm{DPC} \times \mathrm{R} \Delta \mathrm{DIV}+\beta_{1} \mathrm{DNC} \times \mathrm{R} \Delta \mathrm{DIV}+\varepsilon$} \\
\hline & FEM & REM & Pooled OLS \\
\hline \multirow[t]{2}{*}{ Constant } & $.025 * * *$ & $.041 * * *$ & $.040 * * *$ \\
\hline & $(5.51)$ & (11.54) & (11.80) \\
\hline \multirow[t]{2}{*}{$\mathrm{DPC} \times \mathrm{R} \Delta \mathrm{DIV}$} & $1.04 * * *$ & $.224 * * *$ & $.223 * * *$ \\
\hline & (5.77) & (3.84) & $(3.81)$ \\
\hline \multirow[t]{2}{*}{$\mathrm{DNC} \times \mathrm{R} \Delta \mathrm{DIV}$} & .811 & .958 & .958 \\
\hline & $(5.11)$ & $(9.15)$ & $(9.10)$ \\
\hline $\mathrm{N}$ & 688 & 688 & 688 \\
\hline Adjusted $\mathrm{R}^{2}$ & 0.214 & 0.155 & 0.155 \\
\hline Test F & & & $106.12^{* * * *}$ \\
\hline Hausman Test & $16.76 * * *$ & & \\
\hline \multicolumn{4}{|c|}{$\begin{array}{l}\text { Note. This table shows the regression of dividend changes on cumulative abnormal returns (CAR) during the three days, centered on the } \\
\text { dividend change announcement date. CAR is computed by using equation (5). Rate of change in dividends (RADIV) is the change in dividend } \\
\text { per share scaled by previous year dividend. DPC is a dummy variable that takes the value } 1 \text { if dividend increases and zero otherwise; DNC is a } \\
\text { dummy variable that takes the value } 1 \text { if dividend decreases and zero otherwise. The table reports the results estimated using pooled OLS, Fixed } \\
\text { effect model (FEM) and Random effect model (REM). The numbers in parentheses are the t-statistics. Panel A reports regression coefficients of } \\
\text { all dividend change events, while panel B considers only those dividend changes that are positively associated with abnormal stock returns } \\
\text { Panel C considers those dividend change events that fulfill the three conditions: i) dividend changes and cumulative abnormal returns are } \\
\text { positively associated; ii) dividend changes are at least } 5 \text { percent; iii) cumulative abnormal returns are at least } 1 \text { (-1)percent. } \\
\text { *** Significant at the } 0.01 \text { level. }\end{array}$} \\
\hline
\end{tabular}

The REM is the best suitable model for the sample used in panel A, while for panel B and C, the best one is fixed effect model.

For the panel A, based on REM results, we observe that positive dividend changes are positively and significantly correlated with abnormal stock returns. This result suggests that dividend increases convey useful information to the market. The coefficient for dividend decreases is however negative and insignificant. The reason could be that a large number of minor decreases are included in our sample. A small dividend decrease may sometimes be considered as a positive signal. This is notably the case, in recessionary business periods, when investors expect substantial decreases in dividend payments.

For panel B and C, the coefficients for both positive and negative dividend changes are positive and significant at 1 percent level, suggesting that the magnitude of the positive (negative) stock price reaction increases with the intensity of the positive (negative) signals being conveyed. The coefficients for positive (1.04) and negative (0.81) dividend changes are larger than those of panel $\mathrm{A}$ and $\mathrm{B}$. If we assume that dividend change announcements have information content about the future prospects of firms and market forces rationally react to these announcements, then the dividend events of panel $\mathrm{C}$ should have greater association with future earnings.

\section{2) Dividend Changes and Future Earnings Changes (conditioned on market reaction)}

The dividend signaling hypothesis suggests that dividend changes convey information about firms' future prospects. Empirical studies reporting excess returns subsequent to dividend change announcements are seen as 
an evidence in support of this hypothesis (see Travlos, Trigerorgis, \& Vafaes, 2001; Gurgul, Madjosz, Mestel, 2003; Yilmaz \& Gulay, 2006). In this study we assume that investors can distinguish between fake and genuine signals and react accordingly to dividend change announcements. Based on these assumptions we predict that the only dividend changes that should be positively related to subsequent earnings changes are those that are informative, i.e., those that lead to economically significant abnormal returns in the dividend change direction at dividend announcements. This is our hypothesis $2(\mathrm{H} 2)$.

Table 8 reports the regression estimates based on $\mathrm{H}_{2}$. In this regression the firm-year sample include only the dividend changes that are at least $5(-5)$ percent relative to previous year dividends and trigger at least 1 percent excess stock returns during the three days surrounding the date of the dividend change announcement. In addition, these dividend changes should be positively associated with the subsequent abnormal stock returns.

To estimate the coefficients in panel A we follow Fama and MacBeth (1973). First, we estimate intercept and slope coefficients from annual regressions of each year of the sample period 1991-2010, then we compute time-series averages of the cross sectional regression coefficients. $t$-statistics are obtained by dividing the mean values by their standard errors. Panel B, however, presents annual regression coefficients estimates along with their $t$-statistics.

Surprisingly, inconsistent with the dividend signaling hypothesis, the coefficients for both positive and negative dividend changes are insignificant during all the three post dividend change years (see panel A, Table 8). The sign of the coefficient becomes negative for dividend decreases when $\mathrm{T}=2$; while for dividend increases it is negative when $\mathrm{T}=3$. These findings suggest that dividend decreased firms start to recover from losses during the second year after dividend cuts; while the deterioration of the profitability of dividend increased firms starts from the third year after dividend changes. A possible reason for early reversal of profitability of dividend decreased firms is related to management behavior. In the presence of bad news, management, in many cases, elects to take a "big bath" in order to create accounting reserves for the future (e.g., by recognizing restructuring liabilities) or reduce future depreciation charges (e.g., by writing off assets). Consequently, earnings of the dividend change year are significantly reduced. This results in earnings reversal in the following years (see, e.g., Healy and Palepu (1988) and Benartzi et al. (1997).

Panel B of table 8 presents the results of panel A in much more detail. We observe that the coefficient of positive dividend changes is positive and significant only for 10.53 percent $(T=1), 26.32$ percent $(T=3)$, and 10.53 percent $(\mathrm{T}=3)$ of the total 19 years. On the other hand, the coefficients for negative dividend changes remain significant and positive for 36.8 percent $(T=1), 0.0$ percent $(T=2)$, and 10.53 percent $(T=3)$ of the total 19 years.

Table 8. Regression of earnings changes on dividend changes

\begin{tabular}{|c|c|c|c|c|c|c|c|c|c|c|c|c|}
\hline \multicolumn{13}{|c|}{ Panel A: Time series Means of the cross-sectional regression coefficients } \\
\hline \multicolumn{2}{|c|}{ Year } & & & $\beta_{l p}$ & $\beta_{\ln }$ & \multicolumn{2}{|c|}{$\beta_{2}$} & $\beta_{3}$ & $\beta_{0}$ & \multicolumn{3}{|c|}{ Mean Adjusted $\mathrm{R}^{2}$} \\
\hline \multicolumn{2}{|c|}{$\mathrm{T}=1$} & \multicolumn{2}{|c|}{ Mean } & 0.02 & 0.09 & \multicolumn{2}{|c|}{0.14} & -0.05 & -0.01 & \multicolumn{3}{|c|}{0.16} \\
\hline & & \multicolumn{2}{|c|}{ t-statistics } & 1.09 & 1.54 & \multicolumn{2}{|c|}{1.38} & -0.49 & -0.33 & & & \\
\hline \multicolumn{2}{|c|}{$\mathrm{T}=2$} & \multicolumn{2}{|c|}{ Mean } & 0.01 & $-0.07 * * *$ & \multicolumn{2}{|c|}{$0.59 * * *$} & $-0.29 * * *$ & $-0.06 * * *$ & \multicolumn{3}{|c|}{0.53} \\
\hline & & \multicolumn{2}{|c|}{$\mathrm{t}$-statistics } & 1.24 & -1.88 & \multicolumn{2}{|c|}{5.90} & -2.99 & -5.56 & \multirow{3}{*}{\multicolumn{3}{|c|}{0.07}} \\
\hline \multirow{2}{*}{\multicolumn{2}{|c|}{$\mathrm{T}=3$}} & \multirow{2}{*}{\multicolumn{2}{|c|}{$\begin{array}{c}\text { Mean } \\
\text { t-statistics }\end{array}$}} & -0.02 & 0.00 & \multirow{2}{*}{\multicolumn{2}{|c|}{$\begin{array}{c}-0.23^{* * * *} \\
-3.65 \\
\end{array}$}} & 0.09 & $0.04^{* * * *}$ & & & \\
\hline & & & & -0.89 & 0.05 & & & 1.18 & 3.64 & & & \\
\hline \multicolumn{13}{|c|}{$\begin{array}{l}\text { Panel B: Annual cross sectional regression coefficients of dividend changes } \\
\left.E_{T-1}\right) / B_{-1}=\beta_{0}+\beta_{1 P} D P C_{0} \times R \Delta D I V_{0}+\beta_{1 N} D_{N} \times R \Delta C_{0} \times V_{0}+\beta_{2} R_{0} O E_{T-1}+\beta_{3}\left(E_{0}-\right.\end{array}$} \\
\hline \multicolumn{5}{|c|}{$\mathrm{T}=1$} & \multicolumn{4}{|c|}{$\mathrm{T}=2$} & \multicolumn{4}{|c|}{$\mathrm{T}=3$} \\
\hline Year & $\beta_{1 \mathrm{P}}$ & $\mathrm{t}\left(\beta_{1 \mathrm{P}}\right)$ & $\mathrm{B}_{1 \mathrm{~N}}$ & $\mathrm{t}\left(\mathrm{B}_{1 \mathrm{~N}}\right)$ & $\beta_{1 \mathrm{P}}$ & $\mathrm{t}\left(\beta_{1 \mathrm{P}}\right)$ & $B_{1 N}$ & $\mathrm{t}\left(\mathrm{B}_{1 \mathrm{~N}}\right)$ & $\beta_{1 \mathrm{P}}$ & $\mathrm{t}\left(\beta_{1 \mathrm{P}}\right)$ & $\mathrm{B}_{1 \mathrm{~N}}$ & $\mathrm{t}\left(\mathrm{B}_{1 \mathrm{~N}}\right)$ \\
\hline 1991 & 0.24 & 1.11 & -0.19 & -1.10 & -0.08 & -0.47 & -0.05 & -0.31 & 0.00 & -0.04 & -0.06 & -0.37 \\
\hline 1992 & 0.04 & 0.35 & 0.10 & 1.00 & 0.03 & 0.47 & -0.08 & -1.47 & -0.04 & -0.23 & -0.11 & -0.80 \\
\hline 1993 & 0.07 & 0.52 & -0.50 & -2.90 & 0.03 & 0.50 & -0.41 & -5.14 & 0.04 & 0.62 & $\mathbf{0 . 2 8}^{* * *}$ & 3.14 \\
\hline 1994 & 0.06 & 1.30 & $\mathbf{0 . 3 8}{ }^{* * *}$ & 1.88 & $\mathbf{0 . 0 4} * * *$ & 1.87 & -0.04 & -0.38 & 0.04 & 0.92 & -0.41 & -1.56 \\
\hline 1995 & 0.02 & 1.12 & $0.23^{* * *}$ & 2.66 & 0.03 & 1.50 & 0.12 & 1.21 & 0.00 & -0.02 & 0.04 & 0.31 \\
\hline 1996 & -0.01 & -0.93 & $0.22 * * *$ & 2.39 & 0.00 & -0.36 & -0.03 & -0.21 & -0.01 & -0.33 & 0.09 & 0.38 \\
\hline 1997 & 0.08 *** & 1.75 & 0.00 & -0.04 & $\mathbf{0 . 0 6}^{* * *}$ & 1.74 & -0.09 & -0.94 & -0.02 & -0.21 & 0.11 & 0.36 \\
\hline 1998 & 0.01 & 0.35 & 0.19 & 1.72 & 0.01 & 0.02 & -0.05 & 0.07 & $\mathbf{0 . 0 8}^{* * *}$ & 2.12 & 0.04 & 0.11 \\
\hline 1999 & -0.15 & -2.19 & -0.15 & -0.94 & -0.03 & -0.74 & -0.19 & -2.17 & -0.08 & -2.16 & -0.54 & -1.63 \\
\hline
\end{tabular}




\begin{tabular}{ccccccccccccc}
\hline 2000 & -0.01 & -0.36 & $\mathbf{0 . 3 2} * * *$ & $\mathbf{3 . 7 5}$ & -0.02 & -0.79 & 0.05 & 0.75 & -0.18 & -4.03 & -0.30 & -2.24 \\
2001 & -0.03 & -0.64 & -0.17 & -0.99 & 0.02 & 0.58 & -0.43 & -3.48 & -0.04 & -1.30 & 0.12 & 0.79 \\
2002 & 0.01 & 0.19 & $\mathbf{0 . 2 4} * * *$ & $\mathbf{1 . 9 7}$ & 0.01 & 0.41 & 0.14 & 1.28 & 0.01 & 0.32 & -0.12 & -1.08 \\
2003 & 0.02 & 0.38 & 0.09 & 0.84 & 0.04 & 0.86 & -0.02 & -0.20 & 0.01 & 0.21 & -0.09 & -0.72 \\
2004 & 0.00 & -0.15 & 0.01 & 0.08 & 0.00 & 0.04 & -0.06 & -0.72 & 0.01 & 0.24 & -0.09 & -0.22 \\
2005 & $\mathbf{0 . 0 9} * * *$ & $\mathbf{1 . 9 3}$ & 0.24 & 1.50 & $\mathbf{0 . 0 7} * * *$ & $\mathbf{2 . 0 5}$ & -0.12 & -0.94 & -0.36 & -4.57 & 0.17 & 0.51 \\
2006 & -0.07 & -4.93 & $\mathbf{0 . 2 2} * * *$ & $\mathbf{2 . 4 0}$ & -0.03 & -2.32 & -0.04 & -0.60 & $\mathbf{0 . 1 5} * * *$ & $\mathbf{4 . 8 6}$ & $\mathbf{0 . 9 2} * * *$ & $\mathbf{4 . 9 6}$ \\
2007 & 0.00 & 0.04 & $\mathbf{0 . 5 7} * * *$ & $\mathbf{2 . 2 7}$ & -0.01 & -1.60 & 0.11 & 0.81 & 0.00 & -0.18 & 0.02 & 0.12 \\
2008 & 0.03 & 1.13 & -0.03 & -0.38 & 0.02 & 1.44 & -0.05 & -1.14 & & & & \\
2009 & -0.02 & -0.15 & -0.07 & -0.47 & & & & & & & & \\
\hline
\end{tabular}

Note. This table reports regression estimates considering only the dividend changes positively correlated with cumulative abnormal returns. The dividend changes are at least 5(-5) percent and the abnormal returns are at least 1(-1) percent. $\mathrm{E}_{\mathrm{T}}$ is the net earnings in year $\mathrm{T}$ (year 0 is the event year). $\mathrm{B}_{-1}$ is the book value of owner's equity at the end of year ${ }_{-1}$. R $\Delta \mathrm{DIV}$ is the annual rate of change in ordinary dividends, computed as the change in dividends scaled by last year's dividends. DPC (DNC) is equal to one for dividend increases (decreases) and zero otherwise. ROE stands for returns on equity. To estimate coefficients in panel A we follow Fama and MacBeth (1973). First we estimate intercept and slope coefficients from annual regressions of each year of the sample period 1991-2010, then we compute time-series averages of the cross sectional regression coefficients. T-statistics are obtained by dividing the mean values by their standard errors. In panel A and B positive and significant coefficients are highlighted.

Overall, these results do not support the hypothesis that market forces react to dividend change announcements because these changes convey inside information about future earnings. These findings suggest that if dividend changes convey some information, it may not be necessarily regarding the changes in future earnings.

\section{Conclusion}

Since Miller and Modigliani (1961) and Watts (1973), researchers have often examined the relationship between dividend changes and future earnings changes. Most investigate the information hypothesis by examining whether changes in dividends translate directly into changes in future earnings. The empirical studies offer little support for the hypothesis that current dividend changes signal future earnings changes. However, Nissim and Ziv (2001) report some evidence in support of a positive association between dividend changes and future earnings changes in the US. They examine the changes in earnings in the two years following dividend changes. By adding one more year and using their model, we analyze changes in earnings in three years leading dividend changes. Using German and French sample, first we use all dividend change observations to know the association between dividend changes and future earnings. In the second step, we consider only those dividend changes that are at least $5(-5)$ percent, and the subsequent market adjusted abnormal returns, triggered by these changes, are at least 1(-1) percent in the dividend change direction. We find weak evidence in support of the relationship between dividend changes and earnings changes in the two years following dividend change year. Moreover, the sign of the coefficients becomes negative in year 3; indicating a reversal in the performance of dividend changed firms.

\section{References}

Aharony, J., \& Swary, I. (1980). Quarterly Dividend and Earnings Announcements and Stockholders' Returns: An Empirical Analysis. The Journal of Finance, 35(1), 1-12. https://doi.org/10.1111/j.1540-6261.1980.tb03466.x

Al Qudah, A., \& Badawi, A. (2015). The Signaling Effects and Predictive Powers of Dividend Announcements: Evidence from Kingdom of Saudi Arabia. Journal of Business and Economics, 6(3), 550. https://doi.org/10.15341/jbe(2155-7950)/03.06.2015/012

Andres, C., Betzer, A., Bongard, I. van den, Haesner, C., \& Erik, T. (2013). The Information Content of Dividend Surprises: Evidence from Germany. Journal of Business Finance \& Accounting, 620-645. https://doi.org/10.1111/jbfa.12036

Apostolos, D., Lyroudi, K., \& Ginoglou, D. (2009). The impact of dividend initiations on Greek listed firms' wealth and volatility across information environments, 35(6), 531-543.

Asquith, P., \& Mullins, D. W., Jr. (1983). The Impact of Initiating Dividend Payments on Shareholders' Wealth. The Journal of Business, 56, 77-96. https://doi.org/10.1086/296187

Benartzi, S., Michaely, R., \& Thaler, R. (1997). Do Changes in Dividends Signal the Future or the Past? The Journal of Finance, 52(3), 1007-1034. https://doi.org/10.1111/j.1540-6261.1997.tb02723.x 
Bernheim, D. (1991). Tax policy and the dividend puzzle. Rand Journal of Economics, 22, 455-476. https://doi.org/10.2307/2600982

Brav, Alon, Graham, J. R., \& Harvey, C. R. (2005). Payout Policy in the 21st Century. Journal of Financial Economics, 77(3), 483-527. https://doi.org/10.1016/j.jfineco.2004.07.004

Brickley, J. A. (1983). Shareholder wealth, information signaling and the specially designated dividend: An

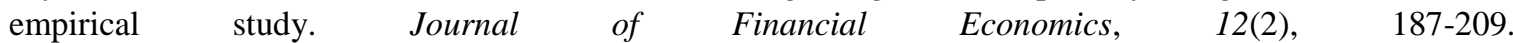
https://doi.org/10.1016/0304-405X(83)90035-1

Chen, T. Y., \& Kao, L.-J. (2014). Dividend changes and information about future profitability: an application of difference GMM. Applied Economics Letters, 21(7), 505-508. https://doi.org/10.1080/13504851.2013.870648

Christie, W. G., Harris, J. H., \& Schultz, P. H. (1994). Why Did NASDAQ Market Makers Stop Avoiding Odd-Eighth Quotes? The Journal of Finance, 49(5), 1841-1860. https://doi.org/10.1111/j.1540-6261.1994.tb04783.x

DeAngelo, H., \& DeAngelo, L. (1990). Dividend Policy and Financial Distress: An Empirical Investigation of Troubled NYSE Firms. Journal of Finance, 45(5), 1415-1431. https://doi.org/10.1111/j.1540-6261.1990.tb03721.x

DeAngelo, H., DeAngelo, L., \& Skinner, D. J. (1996). Reversal of fortune dividend signaling and the disappearance of sustained earnings growth. Journal of Financial Economics, 40(3), 341-371. https://doi.org/10.1016/0304-405X(95)00850-E

Dhillon, U. S., \& Johnson, H. (1994). The Effect of Dividend changes on Stock and Bond Prices. The Journal of Finance, 49(1), 281-289. https://doi.org/10.1111/j.1540-6261.1994.tb04430.x

Grullon, G., Michaely, R., Benartzi, S., \& Thaler, R. H. (2005). Dividend Changes Do Not Signal Changes in Future Profitability. The Journal of Business, 78(5), 1659-1682. https://doi.org/10.1086/431438

Healy, P. M., \& Palepu, K. G. (1988). Earnings information conveyed by dividend initiations and omissions. Journal of Financial Economics, 21(2), 149-175. https://doi.org/10.1016/0304-405X(88)90059-1

Jensen, G. R., Lundstrum, L. L., \& Miller, R. E. (2010). What do dividend reductions signal? Journal of Corporate Finance, 16(5), 736-747. https://doi.org/10.1016/j.jcorpfin.2010.06.009

Koch, A. S., \& Sun, A. X. (2004). Dividend Changes and the Persistence of past Earnings Changes. The Journal of Finance, 59(5), 2093-2116. https://doi.org/10.1111/j.1540-6261.2004.00693.x

Lee, B. S., \& Mauck, N. (2016). Dividend initiations, increases and idiosyncratic volatility. Journal of Corporate Finance, 40, 47-60. https://doi.org/10.1016/j.jcorpfin.2016.07.005

Lee, H. W., \& Ryan. (2000). The Information Content of Dividend Initiations and Omissions: The Free Cash Flow and Dividend Signaling Hypotheses. The Journal of Research in Finance, 3(2), 196-277.

Leftwich, R., \& Zmijewski. (1994). Contemporaneous announcements of dividends and earnings. Journal of Accounting, Auditing \& Finance, 9, 725-762. https://doi.org/10.1177/0148558X9400900406

Liljeblom, E., Mollah, S., \& Rotter, P. (2015). Do dividends signal future earnings in the Nordic stock markets? Review of Quantitative Finance and Accounting, 44(3), 493-511. https://doi.org/10.1007/s11156-013-0415-3

Liu, C., \& Chen, A. S. (2015). Do firms use dividend changes to signal future profitability? A simultaneous equation analysis. International Review of Financial Analysis, 37, 194-207. https://doi.org/10.1016/j.irfa.2014.12.001

Merton, H. M., \& Modigliani, F. (1961). Dividend Policy, Growth, and the Valuation of Shares. The Journal of Business, 34(4), 411-433. https://doi.org/10.1086/294442

Michaely, R., Thaler, R. H., \& Womack, K. L. (1995). Price Reactions to Dividend Initiations and Omissions: Overreaction or Drift? The Journal of Finance, 50(2), 573-608. https://doi.org/10.1111/j.1540-6261.1995.tb04796.x

Nissim, D., \& Ziv, A. (2001). Dividend Changes and Future Profitability. The Journal of Finance, 56(6), 2111-2133. https://doi.org/10.1111/0022-1082.00400

Pettit, R. (1976). The Impact of Dividends and Earnings Announcements: A Reconciliation. The Journal of Business, 1(49), 86-96. https://doi.org/10.1086/295813 
Sant, R., \& Cowan, A. R. (1994). Do dividends signal earnings? The case of omitted dividends. Journal of Banking \& Finance, 18(6), 1113-1133. https://doi.org/10.1016/0378-4266(94)00063-8

Tsai, H. J., \& Wu, Y. (2015). Bond and stock market response to unexpected dividend changes. Journal of Empirical Finance, 30, 1-15. https://doi.org/10.1016/j.jempfin.2014.11.001

Watts, R. (1973). The information content of dividends. Journal of Business, 46, 191-211. https://doi.org/10.1086/295525

\section{Copyrights}

Copyright for this article is retained by the author(s), with first publication rights granted to the journal.

This is an open-access article distributed under the terms and conditions of the Creative Commons Attribution license (http://creativecommons.org/licenses/by/4.0/). 